\title{
Identification Of Heavy Metal Plumbum (Pb) In Edible Offal
}

\author{
E. Harlia ${ }^{1 a}$, R. L. Balia ${ }^{1}$, D. Suryanto ${ }^{1}$ \\ ${ }^{I}$ Faculty of Animal Husbandry, Padjadjaran University \\ aemail: ellin.harlia@unpad.ac.id
}

\begin{abstract}
Plumbum $(\mathrm{Pb})$ is a heavy metal that its presence is undesirable because it can lead to the formation of residues in animal or human body which cause health problems. Pb source can be derived from disinfectant, bedding materials, corrosion equipment, paint, animal feed, water and soil. Livestock farming is difficult to avoid $\mathrm{Pb}$ contamination, so it is important to do research on the identification of $\mathrm{Pb}$ in edible animal offal (pig liver, beef cattle tripe and lamb kidney). This research is an exploratory study on 12 samples of pig liver, 12 samples of beef cattle tripe and 12 samples of lamb kidney which sold in the traditional market in Bandung, the samples were analyzed using AAS machine at Balai Penelitian Veteriner in Bogor, data were analyzed descriptively. The results showed that $50 \%$ of beef cattle tripe contains residues of heavy metals $\mathrm{Pb}$, accounted 0.98 ppm on average, while all samples of pig liver and lamb kidneys contains residues of heavy metals $P b$ with average residues 0.35 ppm and $0.50 \mathrm{ppm}$, respectively. The content of $\mathrm{Pb}$ found on beef cattle tripe, pig liver, and lamb kidney is safe because it below the MRL (Maximum Residue Limits) established by SNI which is $1.00 \mathrm{ppm}$.
\end{abstract}

Key words : Heavy metals, plumbum, pig liver, beef cattle tripe, lamb kidney

\section{Identifikasi Logam Berat Plumbum (Pb) Dalam Edible Offal}

\begin{abstract}
Abstrak
Plumbum $(\mathrm{Pb})$ merupakan logam berat yang tidak diharapkan kehadirannya karena dapat menyebabkan terbentuknya residu dalam tubuh ternak maupun manusia yang mengakibatkan gangguan kesehatan. Sumber $\mathrm{Pb}$ dapat berasal dari desinfectant, bedding material, korosi peralatan; cat, pakan ternak, air dan tanah. Budidaya ternak sulit untuk menghindari kontaminasi logam berat $\mathrm{Pb}$, sehingga penting dilakukan penelitian tentang identifikasi logam berat $\mathrm{Pb}$ dalam edible offal ternak (hati babi, babat sapi potong dan ginjal domba). Penelitian ini merupakan penelitian eksploratif terhadap 12 sampel hati babi, 12 sampel babat sapi potong dan 12 sampel ginjal domba yang dijual di pasar Kota Bandung, sampel dianalisis menggunakan mesin AAS di Balai Penelitian Veteriner Bogor, data yang diperoleh dianalisis secara deskriptif. Hasil Penelitian menunjukkan $50 \%$ babat sapi potong positif mengandung residu Logam berat $\mathrm{Pb}$ dengan rata-rata $0,98 \mathrm{ppm}$, sedangkan 12 sampel hati babi dan ginjal domba $100 \%$ mengandung residu logam berat $\mathrm{Pb}$ dengan rata -rata $\mathrm{Residu} \mathrm{Pb}$ dalam hati babi $0,35 \mathrm{ppm}$ dan residu $\mathrm{Pb}$ dalam ginjal domba 0,50 ppm. Kondisi ini dapat dikatakan aman, karena di bawah BMR (Batas Maksimum Residu) yang ditetapkan SNI yaitu 1,00 ppm.
\end{abstract}

Kata kunci : Logam berat, plumbum, hati babi, babat sapi, ginjal domba 


\section{Introduction}

Food derived from animal should meet food safety requirements which avert from biological, physical and chemical contaminants. The development of the industry, the increasing number of vehicles and the declining number of plants are some factors increasing environmental pollution. Heavy metal contamination such as Plumbum $(\mathrm{Pb})$ can be found in livestock products such as meatball, corned beef, beef burger, and sausage (Harlia and Balia, 2010). Plumbum is a toxic heavy metal which can be contaminant source while activity occurred and turned into bioaccumulation. Source of plumbum pollution in livestock derived from feed are forage, grains and minerals (Mukesh K.R.et al. 2008). Balanced composition of feed can prevent the formation of $\mathrm{Pb}$ residues in livestock organs. Edible offal (tripe, kidneys and liver) is still being consumed by the community. It consumption is increasing each year. Livestock statistical data in 2011, shows the consumption of edible offal in 2010 increased from $0,040 \mathrm{~kg} / \mathrm{capita} /$ year to 0,050 $\mathrm{kg} /$ capita/year. High price of meat can be a reason why people still consuming edible offal. Market of edible offal in Bandung and surrounding areas is centered on the Astana Anyar market. Traders edible offal in the Astana Anyar market specifically sell edible offal (tripe, liver, kidneys, intestines, and heart), both from large and small livestock. Determining maximum residue limits (MRL) in food of animal origin by the government is one effort to maintain the quality of food that is safe for the people of Indonesia. MRL of Plumbum in edible offal has been set by SNI No. 7387 in 2009 is 1 ppm, as well as meat. The purpose and objective of this research is to know food safety of edible offal from cattle, sheep and pigs on Plumbum heavy metal contamination.

\section{Materials And Methods}

Samples edible offal (beef cattle tripe, lamb kidney and pig liver) were obtained from 6 traders in Astana Anyar Market Bandung, with 12 samples of beef cattle tripe, 12 samples of lamb kidney and 12 samples of pig liver. Detection of $\mathrm{Pb}$ is using AAS (Atomic Absorption Spectrometry), samples were analyzed at Laboratorium Toksikologi Balitvet Bogor. This research is an exploratory study, sampling was conducted randomly with total number of samples were 36 samples. Data were analyzed descriptively and compared with the Maximum Residue Limits (MRL) according to SNI No. 7387:2009

\section{Results And Discussions}

The average content of Plumbum $(\mathrm{Pb})$ in edible offal sold in Astana Anyar Market, Bandung, can be seen in Table 1.

Table 1. The residue content of $\mathrm{Pb}$ in edible offal (ppm)

\begin{tabular}{cccc}
\hline Sample & Beef Cattle Tripe & Lamb Kidney & Pig Liver \\
\hline 1 & 1,24 & 0,1530 & 0,3842 \\
2 & 1,53 & 0,6059 & 0,4271 \\
3 & 2,03 & 0,3848 & 0,5073 \\
4 & 0,24 & 0,1102 & 0,4967 \\
5 & 0,24 & 0,6331 & 0,4331 \\
6 & 0,66 & 0,6584 & 0,3275 \\
7 & - & 0,3685 & 0,3373 \\
8 & - & 1,4562 & 0,1466 \\
9 & - & 0,2991 & 0,3978 \\
10 & - & 0,6109 & 0,2607 \\
11 & - & 0,6109 & 0,1832 \\
12 & - & 0,1412 & 0,2352 \\
\hline Summary & 5,90 & 6,0050 & 4,1367 \\
\hline Mean & 0,98 & 0,5004 & 0,3447 \\
\hline SD & 0,7141 & 0,3649 & 0,1180 \\
\hline MRL & & $1,000 \mathrm{ppm}$ & \\
\hline
\end{tabular}




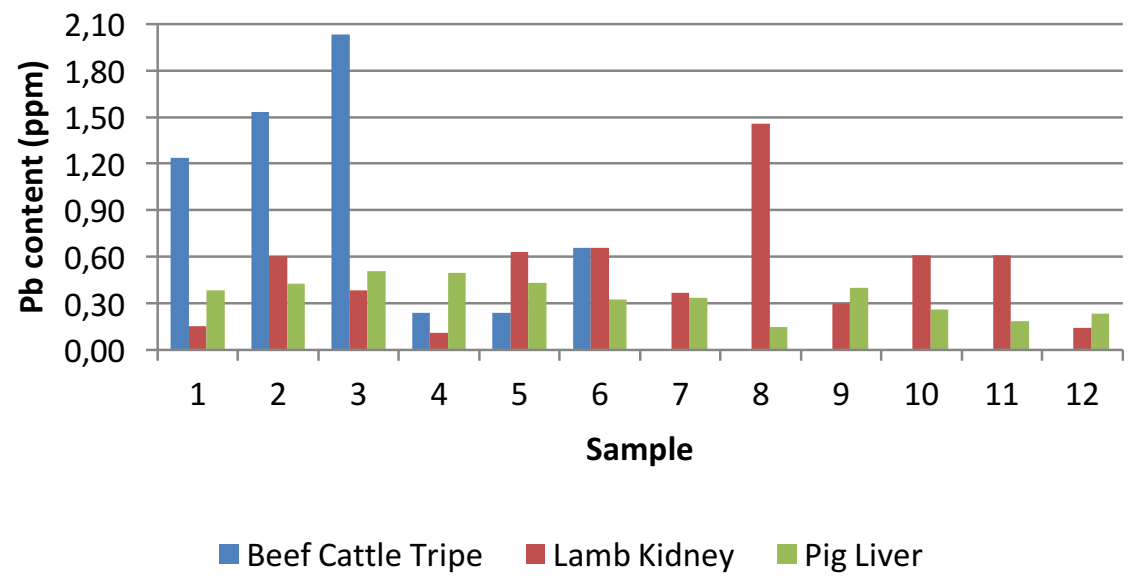

Figure 1. The residue content of $\mathrm{Pb}$ in each sample

Table 1 above showed that $50 \%$ samples of beef cattle tripe containing $\mathrm{Pb}$ residues, and $100 \%$ samples of both kidney lamb and pig liver containing $\mathrm{Pb}$ residues. Sources of $\mathrm{Pb}$ can be retrieved from water, grains and forage. Allegedly forage obtained from a side street or around the highway. Through the vehicle engine exhaust, $\mathrm{Pb}$ is released into the air. Part of it will form compounds in the air freely with other substances, while others will stick to and absorbed by leaves of plant along the road that will be accumulated in liver, kidneys and bones of sheep grazing near the highway (Onggo, 2009; Tangahu et al, 2011). Contamination can occurred from water source consumed by pigs, cattle and sheep. This is in line with findings from Salem et al (2000) and Järup (2003) that the water pollution by $\mathrm{Pb}$ can occur as a result of erosion of heavy metals in plumbing or heavy metals precipitate in the water body. $\mathrm{Pb}$ can enter through digestive tracts, $\mathrm{Pb}$ entering through the food are absorbed or contaminate salivary glands which then poison the body organs, particularly kidneys, liver, heart and intestines. Edwards et al (1976) reported the content of $\mathrm{Pb}$ found in samples of muscle, liver and kidney obtained from supermarket is $0.46 ; 0.5$ and $0.45 \mathrm{ppm}$. Nriagu et al (2009) implied that $\mathrm{Pb}$ contents in an animal which is not contaminated by heavy metals are generally less than $0.1 \mathrm{ppm}$. The strong bond of metal with protein greatly reduced under acidic (low $\mathrm{pH}$ ) as in the stomach or in other tissues at higher $\mathrm{pH}$ (Jakson et al, 2001). $\mathrm{Pb}$ has half-life period of 25-30 days in the metabolic processes of the body, while in fat tissue and kidney $\mathrm{Pb}$ has longer half-life period to several months (Mason et al, 2013).

\section{Conclusion}

The content of $\mathrm{Pb}$ contained in edible offal obtained from Astana Anyar Market Bandung, is still below the maximum residue limit established through SNI No. 7378:2009 which is $1,00 \mathrm{ppm}$.

\section{Recommendation}

Related agencies in the areas have to monitor and provide information to farmer on the procedures for raising livestock properly (Good Farming Practice).

\section{References}

Astawa, Made. 2009. Bahaya Logam Berat pada Makanan. LITBANG. Departemen Kesehatan

Badan Standardisasi Nasional. 2009. Batas Maksimum Cemaran Logam Berat dalam Pangan No. 7387-2009. Pusat Informasi dan Dokumentasi Standarisasi BSN, Jakarta.

Darmono. 1995. Logam dalam Sistem Biologi Makhluk Hidup. Universitas Indonesia Press Jakarta.

Darmono. 2001. Lingkungan Hidup dan Pencemaran Hubungannya dengan Toksikologi Senyawa Logam. UI-Press, Jakarta.

Harlia, E. and Balia, RL. 2010. The Food Safety of Livestock Products (Meatball, Corned Beef, Beef Burger and Sausage) Studied from Heavy Metal Residues Contamination. Animal Production 12 (1):50-54.

Jackson, GS., Murray, I., Hosszu, LLP., Gibbs, N., Walltho, JP., Clarke, AR. And 
Collinge, J. Location and properties of metal-binding sites on the human prior protein. Proceedings of the National Academy of Sciences of the United States of America, vol. 98 No. 15, page 8531-8535.

Järup, L. 2003. Hazards of Heavy Metal Contamination. Br Med Bull (2003) 68 (1): 167-182.

Mason, LH., Harp, JP and Han, DY. $2014 \mathrm{~Pb}$ Neurotoxicity: Neuropsyschological Effects of Lead Toxicity. BioMed Research International Vol. 2014.

Mukesh K. Raikwar, Puneet.Kumar, Manoj.Singh and Anand Singh. 2008. Toxic effect of heavy metals in livestock health.Veterinary World, Vol.1(1):28-3.

Nriagu, J, Boughanen, M., Linda, A., Howe, A., Grant, C., Rattray, R., Vutchkov, M. and Lalor, G. 2009. Levels of As, Cd, Pb, Cu, $\mathrm{Se}$ and $\mathrm{Zn}$ in bovine kidneys and livers in Jamaica. Ecotoxicology and Environmental Safety Vol. 72, Issue 2, February 2009, page 564-571.
Onggo, TM. 2009. Pengaruh Konsentrasi Larutan Berbagai Senyawa Timbal $(\mathrm{Pb})$ terhadap Kerusakan Tanaman, Hasil dan Beberapa Kriteria Kualitas Sayuran Daun Spinasia. Program Pascasarjana S2. Universitas Padjadjaran.

Salem, HM, Eweida, AW and Farag A. 2000. Heavy Metals in Drinking Water and Their Environmental Impact on Human Health. ICEHM2000, Cairo University, Egypt, September, 2000, page 542-556.

Tangahu, BV, SRS. Abdullah, H. Basri, M. Idris, N. Anuar and M. Mukhlisin. 2011. A Review on Heavy Metals (As, $\mathrm{Pb}$ and $\mathrm{Hg}) \quad$ Uptake by Plants through Phytoremediation. International Journal of Chemical Engineering Vol. 2011. 